\title{
The Future of Technology-based Classroom
}

\author{
Mazen Ismaeel Ghareb ${ }^{1}$ and Saman Ali Mohammed ${ }^{2}$ \\ ${ }^{1}$ Department of Computer Science, College of Science and Technology, University of Human Development, Iraq \\ ${ }^{2}$ Department of English, College of Language, University of Human Development, Iraq
}

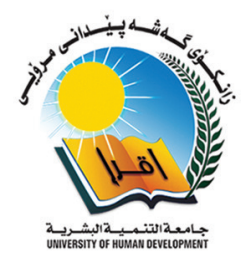

\section{A B S T R A C T}

In recent years, Information Technology has turned out to be a standout among the most essential social practices of the Iraqi society. Technology has developed in many areas in Iraq, yet the internet and computer technology is not implemented in every classroom in most of Iraqi universities. The aim of this paper is to question: Why technology is not executed in the classroom of the universities? The point of this contextual analysis is to recognize the difficulties that face university organizations from executing computer technology in every classroom with support of ministry of higher education. Another question is: How popular or effective could the application of computer communication or computer application in the classrooms of our graduate students be when it comes to education? This study wants to uncover the underlying issues and reasons for the in capabilities in using technology. To examine this, the researchers inspected cases of teaching where technologies used in the classrooms as a lived experience and as an apparatus for encouraging direction while instructing in the universities. The outcomes show that the country's current educational and telecommunications infrastructure is weak and the ministry of higher education and universities need to manufacture the framework limit of schools, and furthermore to enhance educator preparing programs at all levels.

Index Terms: E-classroom, Information Technology, Internet in Education, Iraq Education, Online Learning Applications

\section{INTRODUCTION}

The Iraqi population consists of several ethnic gatherings, including Arab Muslim Shiite, Arab Muslim Sunnis, Kurds, Assyrian, Turkoman, Chaldean, Armenian, Yazidi, Sabean, and Jews. Arabic is the language used in many regions and Kurdish is the official language in Kurdistan [1], and overall designing a curcuilm of using technology will help each ethnic group to express their culture globally with using technology; the key is to be a technology-based classroom context where each individual can work and develop ideas. Thus, technology-based classroom can bring together this melting pot in a diverse country such as Iraq with diverse

\begin{tabular}{|l|l|}
\hline \multicolumn{2}{|c|}{ Access this article online } \\
\hline DOI: 10.21928/uhdjst.v1n1y2017.pp27-32 & $\begin{array}{l}\text { E-ISSN: 2521-4217 } \\
\text { P-ISSN: 2521-4209 }\end{array}$ \\
\hline
\end{tabular}

Copyright (c) 2017 Ghareb and Mohammed. This is an open access article distributed under the Creative Commons Attribution NonCommercial No Derivatives License 4.0 (CC BY-NC-ND 4.0) students in the university. MIT professor Seymour Papert had presented among great debate that the kids were to use computer in their learning. What was all the more shocking was the progressive route in which he led his classes, in open investigation of learning and information that exemplified the general population's PC development of the 1960s. This scene summed up the significance of the change of training and a move in pondering training that fits so well for a fates approach [2].

Thus, could a similar case be witnessed in Kurdistan and/or Iraq? Lei and different researchers demonstrate the significance of utilizing computer technology in learning and profitability. Furthermore, innovation is utilized as a part of instructing and learning techniques in many nations. However, not all the university organizations in Iraq utilize technologies in their classrooms. This review has taken a subjective research approach to examine this issue and recognize the reasons of why the technological tools are not utilized to encourage the procedure of correspondence,

Corresponding author's e-mail: mazen.ismaeel@uhd.edu.iq

Received: 20-03-2017

Accepted: 30-03-2017

Published: 12-04-2017 
improve the strategies for instructing, and enhance the students' learning skills in Iraqi colleges and personnel [3].

\section{LITERATURE REVIEW}

\section{A. Technology and Information Age}

During the previous 50 years, electronic devices (radio, TV, PCs, satellite, and so forth) were the focal instruments and correspondence advances in assisting with transmitting the information to the individuals [4]. The information age has brought new challenges since 1950 where individuals might want to have multimedia sources accessible for them to utilize. The term is used to describe a cybernetic society, which relies upon computer and information transmission.

The commonplace casing of understanding a modern culture depends on the human work and the machines they use to deliver products. In the light of the consistent changes over decades, geographic hindrances are being broken down, and the connection between the employees and their working environment is evolving quickly. New data Information Technology (IT) and types of correspondence have developed to take care of issues and set new bearings for issues that have been around for quite a while. If we take education, for example, we will see that individuals can read, compose, sort, and print by utilizing computer literacy [5]. In many societies, the nature and capacity of technology have changed using computerized advancements in correspondence and in keeping people in general educated on matters of open significance [6].

IT is the reason for changes for the dominant part of businesses. IT is a strategic tool, and without information and technologies, changes are unrealistic especially in a modern age. In the recent years, a large portion of the enterprises everywhere worldwide utilized telecommunicated systems of computers at the center of information systems and communication processes. The development of new technologies makes educating and correspondence all the more effective and less demanding. Technologies do not take care of the social issues, but rather a crucial instrument for improvement and creativity in education in society [7]. Research has demonstrated that the utilization of innovation serves massively crucial by encouraging the learning process where it associates workforce and students with the world. In addition, technology can offer assets and encounters that books are not ready to offer. Computer technology can likewise help with data analysis. They can encourage the administration of vast volumes of information and empower staff, students, or analysts to find, mark, and gather distinctive mixes of portions of literary information [8].

\section{B. The Futures of Educations}

The use investigating the morally stable points of UNESCO's Educating process for a Sustainable Future [9], or the Global Challenges training and learning uncovers the principal and effectiveness of human association with instruction and the importance of training as an extensive advancement apparatus for social monetary change, that is repeated solidly [10]. Training in this regard is one of the problems needs to be addressed when tending to change and what's to come. It is clear that the educational systems do not set us up for the rising pluralistic, interconnected, and complex world. They unquestionably do not set us up for apparently interminable change, insecurity, or more all, instability [11].

Educators and education structures, then need to address this issue of managing ceaseless change and its complexities, new establishments for training. Hicks and Gidley maintain that if teachers do not help youngsters to feel engaged in connection to their future and future change, then, it can be contended, they will have bombed in their obligation to the present era of learners [12]. Thus, these are heated words that place the future eras at the wheel of education and its key approach, as the experience of instruction will shape them, in their expert capacity as well as in their exceptional character, as the Finnish instruction service shows that training basically constructs personality. The moral and good obligation in view of future lives and personalities then could not be as vital or as esteem driven.

\section{Education in Iraq}

Iraq government requires all qualified matured kids to go to grade school. This helped establish the framework for a standout among the most created and proficient populaces in the area. Amid the times of 1970-1984, a period some recognize as the country's "Brilliant years," education system increased huge initiative acknowledgment in Middle East. Today, the Ministry of Education (MOE) and Ministry of Higher Education and Scientific Research (MOHESR) and Ministry of Higher education of Kurdistan Region Government (MOH-KRG) deal with the Iraqi instruction framework [13]-[15].

\section{Computers in the Classroom}

In a presentation on education and learning in 1990, Seymour paper questioned what specialists, futurists, and prophets are asking - what will it resemble? What kind of a world will it be? Furthermore, he states that these could be wrong 
sort of things to ask, as they are all wrong, he said that "the question is definitely not What will the computer do to us?" The question is "The thing that we will make of the computer?" The fact of the matter is defined not to foresee the computer future [16]. The substance of this is the vital position in which training ought to be viewed as proactive and authoritative, that diagram two distinctive perspectives of education, one that is repetitive knowledge based, and the other that is an experience based learning. That the adjustments in our condition do not simply happen to us and impact us, however, we likewise play a part in influencing them. This fits extremely well for a prospect's point of view and helps in exploring moral issues managing technology and education.

On account of this we can get better engagement with kids as dynamic learners and their enabling perspective of training that is exploratory in nature. The landing of the computer in the classroom, blended up with solid moral inquiries regarding the significance of information, educating, and discovering till the present time serves as a key issue that raises key inquiries, for and against technology. We can see this sort of viewpoint today in moral discourses about kids bringing individual innovations such as Mobile smart phones into the classroom. One proposed enactment for instance, announced in the news as of late, recommended that they ought to confiscate smart-phones since they would be a diversion to learn, or that students were tricked in some way, which in particular moral cases are genuine issues confronted for conventional education learning settings [16]. Embracing childhood and youth as engaged through digital media, and consequently for instructive arrangement reflects their strengthening. It recognizes the requirement for a "quiet revolution" in education that saddles the impressive limits of youngsters and youngsters to take part in and coconstruct conceivable future [17].

\section{E. Internet Revolution in Iraq}

In recent years, the Internet technology as methods for communication and its users have been growing drastically. The number of users in Iraq increased after the 2003 war because there were rules feeding using internet [18].Currently, the Internet circumstance is enhanced significantly as there are presently there are many [19]. The last information gathered in regards to non-military personnel access to the Internet was in 2017 and around then roughly 6.381 million Iraqis had home web, positioning $87^{\text {th }}$ for Internet access globally [19]. While this is a an improvement, individuals get to independent companies, educational institutions, and government framework and keep on crippling Iraq in turning out to be globally competitive. The United States (US) government welcomed the financial specialists and enormous organization to invest in Iraq to begin the procedure of the country's reconstruction. In 2004, the United Nations Development Group Iraq Trust Fund (UNDG ITF) began in Iraq. UNDG ITF is one of the International Reconstruction Fund Facility for Iraq (IRFFI). The Iraqi government counseled with the United Nations and the World Bank to plan the IRFFI and open the entryways for contributors and global sources to bolster Iraq's reconstruction activities including technology implementation projects [20].

\section{F. Social Media in Iraq}

Researchers have been inspecting the part that web-based social networking plays in the higher education classroom. A portion of the work has highlighted the full of feeling results of Social Network Sites coordination. A couple thinks about examined learning results and understudy accomplishment in relating to the instructive utilization of online networking in school courses. While the lion's share of studies detailed positive evidence, there was proof of downsides too. Education system does tend toward investigating and developing technologies as new or enhanced apparatuses to upgrade instruction and learning.

Web-based social networking has developed as a profoundly valuable individual correspondence technology. Although the foundation to bolster web-based social networking's nearness exists in many colleges today, teachers have been moderate in receiving the instrument as an instructive one.

A few, obviously, are not willing to acknowledge the apparatus unlimited power favoring theoretical or pragmatic reasons for an implementation [21]. Adding to that there are many students and undergraduates who spent a lot of time on social network, making many groups of study. Many lecturers also have been interacting about the subjects, assignments, and courses on social media guiding and giving the students instructions [22].

\section{METHODOLOGY}

The aim of this research is to recognize the difficulties that face the universities administrations from implementing the computer technology in every classroom. This study attempts to answer the accompanying research question: Why the technology is not implemented yet in the classroom settings in the Iraqi and KRG colleges? This review takes after a qualitative research way to examine the issue. 


\section{G. The Iraqi Education System}

The models in country risk analysis, for example, the Economic Intelligence Unit, Business Environment Risk Intelligence, and Euro money help organizations and their administrations see well which nation is a decent market for speculation and which one is not to maintain a strategic distance from misfortunes to their organizations. These models function as a hazard appraisal to help firms in settling on market passage choices, operations principles, and leave procedure choices. These models and strategies incorporate essential data on Iraq's political circumstance, legal, investment overview, social, cultural, environmental, and geological dangers of the nation. The reports on Iraq from these models were not positive which make it harder for the Iraqi government to move quickly with the innovation execution extends in the scholarly organizations. In spite of the fact that the utilization of computer technology in classroom settings can help in encouraging the educating and enhancing the student's learning aptitudes, the classrooms in Iraqi universities still do not have the accessibility of this technology because of a few difficulties that the nation faces. These difficulties will be clarified in the accompanying sections.

\section{RESULTS AND DISCUSSIONS}

We as the researchers of this paper, have been observing some English and computer teaching classes in some of Kurdistan universities such as University of Human Development as a private one and Sulimanya university as the state University in Iraq. The English training in Iraq depends on conventional instructional strategy and generally the class size is extensive. The quantity of students is around 30-50 in each class. The technique in which the understudies learn English is an educator focused. Perusing understanding takes a substantial piece of class time and linguistic use is essential. Talking and listening appear to be disregarded in showing English as an outside dialect in Iraq. Moreover, little gathering work, which is common with the communicative teaching method (the strategy more generally acknowledged by remote language instructors these days), is disregarded in the Iraqi classroom, which is also teacher-centered instead of student-centered. Regarding the programming teaching, Mazen experienced the lack of infrastructure for students to publish their software product and no support from government as small business projects [23]. As interview with several professors, they do not use the computer technologies to encourage learning through online talk bunches, watching the recordings and clasps inside the classroom, talking and recordings, and so on because of the absence of language laboratories or computer technology in classrooms. This issue is as yet present in Iraq till now the same number of my associates who still sit-in Iraq told me of these ongoing problems.

Getting to online instructional materials and the utilization of Blackboard apparatuses in Iraqi organizations is as yet not accessible to all public and private universities in Iraq. However, University of Human development uses Moodle tool. Moodel is used as an open source for our teaching using online forums, assignments, and online quizzes. In addition, we have experience using social media for group working as an effective method in learning process [24]. The Iraqi and the US governments have been attempting to modernize the instructional framework and to improve online instructive libraries. This incorporates building instructive organizations among Iraqi and US schools, trade projects and going by researchers, and supporting Iraqi understudies and instructor to examine or to get prepared in the US foundations. In spite of the fact that this support is exceptionally useful, the overall progress is very slow [25].

\section{CONCLUSIONS AND RECOMMENDATIONS}

The research findings show that if country risk analysts contrast Iraq's education, technological status with other developed countries such as the USA, they can see that getting to online instructional materials in Iraqi establishments is still not of that high quality, and the nation's current educational and media communications infrastructure is weak. In addition, Iraq confronts various difficulties after the 2003 war. One of these difficulties was to recover the unmistakable quality that its instruction framework once held in the Middle East, the need to construct the foundation limit of schools, and furthermore to enhance instructor preparing programs at all levels [26].

In view of the unsecure circumstance and the political instability in Iraq, it is difficult to execute technology in all schools in a short time. Therefore, the alternatives recognized are to have a PC laboratory, technology tools, and the internet in each school as an initial step to encourage learning and instructing. Having such a lap is an essential official unit unlike Smartphone. Having Internet café undergrad and graduate students to use for their class study and research. Since so many students have Smartphone and tablets, the use of internet and the technology-based classroom becomes easy if there are adopted mechanisms. The recommendations outlined in this research are as follows: The universities must 
have a correct time span for finishing the outline and the cost of their technology-based systems, classrooms, and project. It ought to likewise determine which schools that can profit by the technology implementation. There ought to likewise be a political strength and security in the nation to ensure the specialists and associations that will take the venture and play out the business. The universities have likewise to empower Iraqi lecturers and students to go to workshops and gatherings to acquire information and improvement. MOE and MOHESR may contract worldwide staff and personnel to help with the educational development process and technology used in classrooms. Sending Iraqi students to consider in foreign countries will be an advantage for the country once they come back to exchange with the nearby staff their own experiences and knowledge. We recommend the other public and private university using new technological tools for their educational process. For instance, university of Human Development has used Moodle tool as an open source for their students which has positively affected the capabilities of interact with the students and teaching activities in university and later outside the university [24]. This system is upgrade to Google applications and all the students have their own university account and it will be configured to Google class next year. Furthermore, students can use many social media applications for educational communication such as Facebook, Viber, and many more.

\section{ACKNOWLEDGMENT}

We would like thanks University of Human Development for usual support to conduct this research, and for all students and lectuere that support us during analysis data of this study.

\section{REFERENCES}

[1] J. Ainsworth, Ed. Sociology of Education: An A-to-Z Guide. Thousand Oaks, CA: Sage Publications, 2013.

[2] D. C. Hoyles and R. Noss. "Visions for mathematical learning: The inspirational legacy of seymour papert (1928-2016)." EMS Newsletter, vol. 3, no. 103, pp. 34-36, 2017.

[3] J. Lei, J. Shen and L. Johnson. "Digital technologies and assessment in the twenty-first-century schooling." in Assessing Schools for Generation R (Responsibility), Netherlands: Springer, 2014, pp. 185-200.

[4] M. M. Teixeira, C. D. de Aquino, M. B. C. Leão, H. V. L. Souza, R. F. F. de Oliveira, L. Miranda, R. Neves and E. Medeiros. "Mass media in teaching and learning: Circumstances in higher education." in Information Systems and Technologies (CISTI), $201611^{\text {th }}$ Iberian Conference on IEEE, 2016, Jun. pp. 1-5.

[5] T. Gillespie, P. J. Boczkowski and K. A. Foot. Media Technologies: Essays on Communication, Materiality, and Society. Cambridge, Massachusetts: MIT Press, 2014.
[6] J. Jordan-Meier. "The Four Stages of Highly Effective Crisis Management: How to Manage the Media in the Digital Age." Boca Raton: CRC Press, 2016.

[7] L. S. Sidhu and J. Sharma. "Information, globalization through research and social development." COMPUSOFT, An International Journal of Advanced Computer Technology, vol. 4, no. 5, pp. 1760, 2015.

[8] T. A. Schwandt. "The Sage Dictionary of Qualitative Inquiry." Thousand Oaks, CA: Sage Publications, 2014.

[9] A. E. Wals. "Sustainability in higher education in the context of the UN DESD: A review of learning and institutionalization processes." Journal of Cleaner Production, vol. 62, pp. 8-15, 2014.

[10] E. Unterhalter. "Measuring education for the millennium development goals: Reflections on targets, indicators, and a post2015 framework." Journal of Human Development and Capabilities, vol. 15, no. 2-3, pp. 176-187, 2014.

[11] A. Montuori. "Creative inquiry: Confronting the challenges of scholarship in the $21^{\text {st }}$ century. Futures, vol. 44 , no. 1 , pp. $64-70$, 2012.

[12] D. Hicks and J. Gidley. "Futures education: Case studies, theories and transformative speculations." Futures, vol. 44, no. 1, pp. 1-3, 2012.

[13] J. H. Issa and H. Jamil. "Overview of the education system in contemporary Iraq." European Journal of Social Sciences, vol. 14, no. 3, pp. 360-386, 2010.

[14] S. Al-Husseini and I. Elbeltagi. "Knowledge sharing practices as a basis of product innovation: A case of higher education in Iraq." International Journal of Social Science and Humanity, vol. 5, no. 2, pp. 182, 2015.

[15] N. Kaghed and A. Dezaye. "Quality assurance strategies of higher education in Iraq and Kurdistan: A case study." Quality in Higher Education, vol.15, no. 1, pp. 71-77, 2009.

[16] A. Taylor. "Technology in the classroom-the ethical futures of a transforming education." Coolest Student Papers at Finland Futures Research Centre, vol. 2015-2016, pp. 15, 2016.

[17] A. Craft. "Childhood in a digital age: Creative challenges for educational futures." London Review of Education, vol. 10, no. 2, pp. 173-190, 2012.

[18] K. M. Wagner and J. Gainous, J. "Digital uprising: The internet revolution in the middle east." Journal of Information Technology and Politics, vol. 10, no. 3, pp. 261-275, 2013.

[19] R. W. Abedalla, L. S. Escobar and D. A. Al-Quraishi. Accessing information technology-social media in Iraq." International Journal of Scientific and Research Publications, vol. 4, pp. 32, 2014.

[20] UNESCO Institute for Statistics. "Global Education Digest 2010: Comparing Education Statistics across the World." Montreal, Quebec: UNESCO-UIS, 2010.

[21] P. A. Tess. "The role of social media in higher education classes (real and virtual)-a literature review." Computers in Human Behavior, vol. 29, no. 5, pp. A60-A68, 2013.

[22] M. I. Ghareb and H. O. Sharif. "Facebook effect on academic performance and social life for undergraduate students of university of human developments." International Journal of Multidisciplinary and Current Research, vol. 3, pp. 811-820, 2015.

[23] M. I. Ghareb and S. A. Mohammed. "The effect of e-learning and the role of new technology at university of human development." International Journal of Multidisciplinary and Current Research, vol. 4, pp. 299-307, 2016. 
[24] M. I. Ghareb and S. A. Mohammed. "The role of e-learning in producing independent students with critical thinking." International Journal of Multidisciplinary and Current Research, vol. 4, pp. 299307, 2016.

[25] A. D. Andrade and B. Doolin. "Information and communication technology and the social inclusion of refugees." Mis Quarterly, vol. 40, no. 2, pp. 405-416, 2016.

[26] A. G. Atiya and M. Vrazhnova. "Higher education funding in Iraq in terms of the experience of particular developed countries." International Journal of Advanced Studies, vol. 6, no. 1, pp. 8-17, 2017. 